\title{
Bitkisel Sterollerin/Stanollerin Aterosklerotik Süreç ve Kardiyovasküler Hastalıklar Üzerine Etkisi
}

\author{
Effects of Plant Sterols/Stanols on Atherosclerotic Process and Cardiovascular Diseases
}

\author{
Hande Çekici ${ }^{1}$, Hilal Yıldıran ${ }^{2}$ \\ ${ }^{1}$ Recep Tayyip Erdoğan Üniversitesi, Sağlı Yüksekokulu, Beslenme ve Diyetetik Bölümü, RİZE, TÜRKIYYE \\ ${ }^{2}$ Gazi Üniversitesi, Sağlık Bilimleri Fakültesi, Beslenme ve Diyetetik Bölümü, ANKARA, TÜRKIYYE. \\ Yazıșma Adresi / Correspondence: \\ Hande Çekici \\ T.C. Recep Tayyip Erdoğan Üniversitesi Sağlık Yüksekokulu İslampaşa Mah. Şehitler Cad. Araştırma Hastanesi Yanı Merkez/RİZE, TÜRKIYE \\ T: +904642141059 E-mail: handecekici@hotmail.com \\ Geliş Tarihi / Received : 14.02.2019 Kabul Tarihi / Accepted : 30.05.2019 \\ Orcid : \\ Hande Çekici https://orcid.org/0000-0001-9377-888X \\ Hilal Yıldıran https://orcid.org/0000-0001-7956-5087
}

Öz

Dünya genelinde kardiyovasküler hastalıklardan kaynaklanan morbiditenin ve mortalitenin ciddi rakamlara ulaștı̆ı bilinmektedir. Günümüzde, yașam tarzının ve beslenme alışkanlıklarının değişmesi ile kardiyovasküler hastalıkların morbiditesi artmıştır. Besinlerin bitkisel sterolleri/stanolleri, enterohepatik döngü içindeki kolesterol ve lipid düzenleyici hedeflerin regülasyonunu sağlayarak kardiyovasküler hastalıkların morbiditesini değiștirebilir ve düzeltebilir. Bitkisel sterollerin/stanollerin bağırsak lümeninde eksojen (diyet) ve endojen kaynaklı kolesterol ile rekabet etmek, bağırsak kolesterolü emilimini azaltmak ve kolesterol sentezinde görevli genlerin ifadesini değiştirmek gibi önemli etkileri vardır. Bitkisel steroller/stanoller hepatik döngü içerisindeki etkinliği ile kardiyovasküler hastalıklar için risk faktörü olan toplam kolesterol, düşük yoğunluklu lipoprotein kolesterol ve trigliserit konsantrasyonlarını önemli ölçüde düşürmektedir. Ayrıca, bitkisel steroller/stanoller aterosklerozun patogenezinde önemli rol oynayan trombotik seviyeleri ve plazma fibrinojen seviyelerini düșürerek aterosklerotik süreç üzerinde etkilidir. ( Sakarya Tip Dergisi 2019, 9(2):218-229)

Anahtar kalp ve damar hastalıkları; fitosteroller; ateroskleroz

Kelimeler

Abstract

It is known that the morbidity and mortality caused by cardiovascular diseases in worldwide have reached to serious levels. Nowadays, the morbidity of cardiovascular diseases has increased due to changing lifestyle and nutrition habits. The plant sterols/stanols of nutrients may alter and improve the morbidity of cardiovascular diseases through regulation of cholesterol and lipid regulatory targets in the enterohepatic cycle. Plant sterols/stanols have important effects in the intestinal lumen such as competing with exogenous (dietary) and endogenous cholesterol, reducing the absorption of intestinal cholesterol, and altering the expression of genes involved in cholesterol synthesis. Plant sterols/stanols significantly reduces the concentration of low density lipoprotein cholesterol and triglyceride and total cholesterol which is a risk factor for cardiovascular diseases with its efficacy in the hepatic cycle. In addition, plant sterols/stanols have influence upon atherosclerotic process by decreasing thrombotic levels and plasma fibrinogen levels that play an important role in the pathogenesis of atherosclerosis. ( Sakarya Med J 2019, 9(2):218-229)

Keywords cardiovascular diseases; phytosterols; atherosclerosis 


\section{GIIRIŞ}

Kardiyovasküler hastalıklar ve ateroskleroz, tüm dünyada, özellikle endüstrileşmiş toplumlarda en önemli morbidite ve mortalite nedeni olarak gösterilmektedir. ${ }^{1}$ Dünya çapında yılda 17 milyon, Avrupa Birliği'nde ise 2 milyon birey kardiyovasküler hastalıklara bağlı olarak yaşamını yitirmektedir. Türkiye'de ise bu rakamın yaklaşık olarak 200 bin olduğu düşünülmektedir. ${ }^{2}$ Türkiye Erişkinlerde Kalp Hastalığı ve Risk Faktörleri Sıklığı Taraması (TEKHARF) verilerine göre, ülkemize ait koroner kalp hastalığı prevalansı, otuz beş yaş ve üzeri popülasyonda 1990 yılına ait veriler ile karşılaştırıldığında 2008 yılında yılda ortalama \%3 artış ile yaklaşık \%80-85 oranında artmıştır. TEKHARF kohortunun bütününde 26 yılda kaydedilen toplam 906 ölümün \%42'sinin koroner hastalıklar, \%12'sinin ise serebrovasküler hastalıklar kaynaklı olduğu bildirilmiștir. ${ }^{3}$ Türkiye İstatistik Kurumu (TÜİK) tarafından 2018 yılına ait ölüm nedenleri istatistikleri açıklanmış ve ölüm vakalarının \%38,4'ünün dolaşım sistemi hastalıkları nedeniyle gerçekleştiği belirtilmiştir. ${ }^{4} \mathrm{Bu}$ iki veri değerlendirildiğinde tüm ölümlerin yarısından aterosklerozun sorumlu olabileceği söylenebilir. ${ }^{5}$ Mortaliteden yüksek oranda sorumlu tutulan kalp krizleri ve inmelerin temel sebebi atardamar duvarlarının kalınlaşması ve sertleşmesi ile gelişen aterosklerozdur. ${ }^{1}$

Ateroskleroz, yağlı çizgilenmeler ile damar lümenini daraltan ve elastik arterlerin intima tabakasında lezyonların ve aterom plakların görüldüğü kronik inflamatuar bir süreçtir. ${ }^{5}$ Aterosklerozun patogenezi henüz netlik kazanmasa da çeşitli hipotezler ileri sürülmektedir. Çoğu hipotezin hemfikir olduğu etkin mekanizma ise plazma lipid bozuklukluklarıdır. Koroner ateroskleroz lipid bileşenleri, inflamatuar komponentleri, fibröz dokuyla seyreden hematomu, kanama veya trombotik depozitleri içeren karmaşık lezyonlara bağlıdır. ${ }^{1}$ Plazma lipid bileşenleri, inflamatuar komponentler ile birlikte aterosklerotik plak oluşumuna katkıda bulunur. ${ }^{5}$ Serum kolesterol seviyelerinin yükselmesi durumunda, kandaki lökositler endotel tabakaya bağlanmaya başlayarak endotelin koruyucu fonksiyonunun bozulmasına yol açmaktadır. ${ }^{6}$ Bununla birlikte, oksidasyona uğrayan düşük dansiteli lipoprotein kolesterol (LDL-K) hücre içindeki nitrik oksit seviyesinin azalmasına neden olmakta ve biyolojik ifadeyi değiştirmektedir. Bahsi geçen tüm endotelyal değişimler, inflamasyonu tetikleyerek aterosklerotik lezyonların oluşumuna ve ilerlemesine zemin hazırlamaktadır. ${ }^{6}$ Arter duvarına konuşlanan inflamatuar faktörler, endotelin yüzey yapısında değişime neden olur ve endotelin serum LDL-K alımını artırır. Artan LDL-K seviyelerinin oksidasyona uğraması ile aterosklerozun oluşum süreci başlamış olur. Okside LDL-K’nın, makrofajlar aracılığıyla hücre içine alınması ile köpük hücrelerinin oluşumu gerçekleşmektedir. Ayrıca, Okside LDL-K vasküler inflamasyon ve aterosklerotik inflamatuar sürece katkısı olan monosit kemoatraktan protein-1 (MCP-1) kemokininin sekresyonunu artırmaktadır. Böylece, daha fazla monositin endotel yüzeye infiltrasyonuna yol açmakla birlikte makrofaj koloni uyarıcı faktör salınımı ile aşırı düzeyde makrofaj üretilmesine neden olmaktadır. Makrofaj konsantrasyonun yükselmesi ise artan köpük hücre oluşumu ile sonuçlanmaktadır. Köpük hücrelerinin birikimi, düz kas hücrelerinde gerçekleşen göç ve proliferasyonun artışı intimanın kalınlaşmasına neden olmakta ve tüm bu gelişmenin sonucunda, aterosklerotik olaylar zinciri başlamaktadir. ${ }^{1}$

Günümüzde sağlıksız beslenme alışkanlıkları (yüksek düzeyde doymuş yağ ve şeker, düşük düzeyde posa alımı gibi batı tarzı beslenme vb.) kardiyovasküler hastalıklar, obezite, diyabet ve kanser gibi en yaygın görülen kronik hastalıkların morbiditesini etkilemektedir. ${ }^{7}$ Özellikle kalp damar hastalıkları gelişimini en aza indirmek için sağlıksız yaşam tarzı ve sağlıksız beslenme alışkanlığının sağlıklı davranışlara dönüştürülmesi önerilmektedir. Kalp damar hastalığının tedavi sürecinde tıbbi tedavi ile birlikte terapötik yaşam tarzı değişikliği çerçevesinde sağlıklı beslenme alışkanlığının benimsenmesi, fiziksel aktivitenin artırılması ve vücut ağırlığı yönetiminin sağlanması oldukça önemlidir. Beslenme tedavisinde alınan doymuş yağ miktarının toplam alınan enerjinin $<\% 7$ 'sine, koles- 
terol alımının <200 mg/gün'e çekilmesi, 10-24 g/gün posa alımı hedeflerinin yanında LDL-K düşürücü etkisi ile bitkisel sterollerin/stanollerin $2 \mathrm{~g} /$ gün alımı öneriler arasında yer almaktadır.8 Amerikan Ulusal Kalp Akciğer ve Kan Enstitüsünün (NHLBI) Ulusal Kolesterol Eğitim Programı ve Avrupa Ateroskleroz Derneği bitkisel sterol veya stanol tüketiminin (2 g/gün) kolesterol seviyelerini düşüreceğini belirtmiştir. ${ }^{8,9}$

Bitkisel steroller/stanoller, bitkilerin yapısında yer alan ve insan sağlığı için çeşitli biyoaktif özelliklere sahip önemli sterollerdir. ${ }^{10}$ Bitkisel sterollerin/stanollerin aterosklerotik sürecin gelişiminde rolü olan lipid bileşenlerinden LDL-K serum seviyelerini, kolesterolün bağırsaktaki emilimini azaltarak düşürdüğü bilinmektedir. Ayrıca, bazı kanser türlerine (meme, mide, prostat vb.) karşı koruyucu etkileri ile birlikte antibakteriyel, antifungal ve antiülser etkileri olduğu öne sürülmektedir. ${ }^{11} \mathrm{Bu}$ derleme makalede, bitkisel sterollerin/stanollerin aterosklerotik süreç ve kardiyovasküler hastalıklar üzerine olası etkileri ve etki mekanizmalarını ortaya koymak amaçlanmıştır.

\section{Bitkisel Sterollerin/Stanollerin Tanımı ve Besinsel Kaynakları}

Bitkisel steroller, çeşitli mekanizmalar yoluyla kolesterol emilimini azaltan bitki temelli steroller olarak bilinirler.

C-17 pozisyonunda bir tetrasiklik yapı ve yan zincirden oluşan triterpen ailesinin üyeleridir. ${ }^{10}$ Yan zincirde, çoğunlukla C-22 ve C-23 arasında çift bağlar içermektedir. Çift bağların pozisyonu ve sayılarının yapısal varyasyonları nedeni ile 250'den fazla bitkisel sterol çeşidi mevcuttur. Serbest bitkisel steroller, genellikle B-halkasında C-5 ve C-6 veya C-7 ve C-8 arasında bir çift bağ içerirler, sırasıyla $\Delta 5$-steroller ve $\Delta 7$-steroller olarak da adlandırılırlar. Çoğu bitki $\Delta 5$-sterol bakımından zengindir. ${ }^{12}$ Temel bitkisel steroller; kampesterol (24- $\alpha$-metilkolesterol), $\beta$-sitosterol (24-a-etilkolesterol) ve stigmasteroldür $(\Delta 22,24$-a-etilkolesterol). $\alpha$-sitosterol dominant formdur (\%62) ve bunu kampesterol (\%21) ve stigmasterol (\%4) izlemektedir.13 Doymuş bir halka yapısına sahip steroller ise bitkisel ste- rollerin bir alt grubu olarak kabul edilen stanoller olarak adlandırılmaktadır. ${ }^{12}$ Bitkisel stanoller, bitki sterollerinin 5a-doymuş türevleridir. Bitkisel steroller, kolesterol yap1sına benzerlikleri ile bilinirler, ancak yapılarında C-24'te bir metil veya bir etil grubunun farklı olmasıyla kolesterolden ayrilırlar. ${ }^{10}$

Bitkisel sterollerin/stanollerin iyi kaynakları tam tahıllar, sebzeler, bitkisel yağlar, yağlı tohumlar ve meyvelerdir. Toplam bitkisel sterol içeriği en yüksek besinler olarak yağlı tohumlar ve fındıklar gösterilmektedir. Tüm bitkisel yağlar, özellikle mısır yağı, kolza tohumu yağı ve buğday tohumu yağı yüksek oranda bitkisel sterol içeriğine sahiptir. Kolza tohumu yağı, 4500-14000 mg/kg bitkisel sterol içermesi ile en iyi kaynak olarak gösterilmektedir. ${ }^{12}$ Misır yağ $686-952 \mathrm{mg} / 100 \mathrm{~g}$ bitkisel sterol, 22-33 mg/100 g bitkisel stanol içermektedir. Kanola yağı ise $250-767$ mg/100 g bitkisel sterol, 2-12 mg/100 g bitkisel stanol içermektedir.14 Durum buğdayı 871-1106 mg/kg, çavdar 1098-1420 $\mathrm{mg} / \mathrm{kg}$, arpa $899-1153 \mathrm{mg} / \mathrm{kg}$ ve yulaf $618-682 \mathrm{mg} / \mathrm{kg}$ bitkisel sterol içeriği ile diğer önemli kaynaklar arasında gösterilmektedir. ${ }^{12}$ Yağlı tohumlardan ceviz 1144-1679 mg/kg, badem 1126-2777 mg/kg toplam bitkisel sterol içermektedir. Ayrıca, çam fistığının, antep fıstığının ve şam fıstığının da yüksek oranda bitkisel sterol içerdiği bilinmektedir. ${ }^{12}$ Ülkemizde yapılan bir araştırmada; fındık yağının toplam bitkisel sterol içeriği 683-1544 mg/kg, kanola yağının ise toplam sterol içeriği 6088-9532 mg/kg düzeyinde saptanmıştır. ${ }^{15}$ Türkiyede üretilen zeytinyağının ise toplam bitkisel sterol içeriği 1025-1686 mg/kg düzeyinde bulunmuştur. $^{16}$

Batı tipi bir diyet günlük yaklaşık 200-500 mg kolesterol ve 200-400 mg bitkisel sterol içermektedir. ${ }^{10}$ Bitkisel sterollerin alım miktarı ülkelere ve kültürel farklılıklara göre değişebilmektedir. Avrupa Prospektif Kanser ve Beslenme Araştırmasına göre Hollanda'da toplam bitkisel sterol alımı 295.8 土 49.2 mg/gündür. ${ }^{17}$ Belçika’ da kadınların ortalama bitkisel sterol alımı $218 \mathrm{mg} /$ gün, erkeklerin ise 280 mg/gün'dür. ${ }^{18}$ Avrupa Prospektif Kanser ve Beslenme 
Araştırması Norfolk popülasyona ait bitkisel sterol alımını erkekler için 300 mg/gün, kadınlar için 293 mg/gün olarak saptamıștır. ${ }^{19}$ Benzer şekilde, İspanya'da $315 \mathrm{mg} /$ gün ${ }^{20}$, Çin'de $317 \pm 127 \mathrm{mg} /$ gün ${ }^{21}$ düzeyinde bitkisel sterol alımı olduğu bildirilmektedir. Akdeniz tipi beslenmede bitkisel sterollerin önemli kaynaklarına (bitkisel yağlar, tahıllar ve sebzeler) oldukça yer verilmektedir. ${ }^{22}$ Akdeniz diyeti tarzı beslenme şekli ile en az 370-555 mg/gün bitkisel sterol alınabildiği bilinmektedir. ${ }^{23}$ Amerika'da ise toplam bitkisel sterol alımının vejetaryen olmayanlarda $263 \mathrm{mg} / \mathrm{gün}$, veganlarda ise $428 \mathrm{mg} /$ gün olduğu görülmüştür. ${ }^{24}$

\section{Bitkisel Sterollerin/Stanollerin \\ Emilimi ve Metabolizması}

Bitkisel sterollerin/stanollerin, kolesterol ile yapısal benzerliklerinin olması kolesterol ile benzer emilim ve taşıma mekanizmasına sahip olduklarını düşündürmektedir. ${ }^{14,25-27}$ Besinlerden alınan bitkisel sterollerin emilebilmesi için miseller içine çözünmeleri ve enterosit içerisine girebilmeleri gerekmektedir. ${ }^{28}$ Bitkisel sterollerin misellere olan afinitesinin kolesterolün afinitesinden daha fazla olduğu düşünülmektedir. Bitkisel steroller/stanoller kolesterolden daha hidrofobik yapıda olmalarından dolayı misellere katılma sürecinde kolesterolü engelleyerek yerine geçebilmektedir. Bu yerine geçme durumu, misellerdeki kolesterol konsantrasyonlarının düşmesine sebep olarak kolesterol emilimini azaltmaktadır. ${ }^{29}$ Enterositlerin içine dahil olan bitkisel sterollerin sistemik emilimleri ATP bağlayıcı kaset G5 (ABCG5) ve ATP bağlayıcı kaset G8 (ABCG8) proteini tarafından yönetilmektedir. ABCG5 ve ABCG8, bitkisel sterolleri ve esterleştirilmemiş kolesterolü enterositten intestinal lümene taşımaktadır. Bitkisel steroller, ABCG5 ve ABCG8 taşıyıcıları tarafından kolesterolden çok daha fazla oranda bağırsağa geri salınır ve bu durum kolesterolden daha düşük bağırsak emilimine yol açmaktadır. ${ }^{28}$ Bitkisel steroller için bağırsak emilim oranı \%0.5-2.0, bitkisel stanoller için ise \%0.04-0.2'dir. ${ }^{30}$ Enterosit içerisindeki bitkisel steroller şilomikronlara dahil edilerek dolaşıma katılmaktadır. ${ }^{28}$ Bununla birlikte, bitkisel steroller/stanoller enterosit içerisindeki kolesterolün esterleşme oranını düşürerek şilomikronlar yoluyla salgılanan kolesterol miktarını azaltabilmektedir. ${ }^{29}$ Şilomikronlara eklenen bitkisel steroller dolaşımına girerek karaciğer tarafından alınmaktadır. ${ }^{25,26}$ Karaciğerde çeşitli enzimlerin etkisiyle kolesterol ve diğer metabolitlere metabolize edilirler, kolesterol 7a-hidroksilaz enzimi ile safra asitlerine dönüştürülürler. Bitkisel sterollerin safraya salgılanmasının kolesterolün safraya salg1lanmasından daha yüksek olduğu bildirilmiştir. ${ }^{28}$ Emilen bitkisel steroller karaciğer tarafından tutulur ve safra yolu ile tekrar bağırsaklara salınırlar. Karaciğer temel depo organidir. $^{25,26}$

Bitkisel sterollerin dolaşımdaki seviyeleri kolesterol seviyelerinden 500 kat, bitkisel stanollerin ise 10.000 kat daha düşüktür. Bitkisel sterollerin ve stanollerin dolaşımdaki seviyeleri sirasiyla 7-24 $\mu \mathrm{mol} / \mathrm{L}(0.3-1.0 \mathrm{mg} / \mathrm{dL})$ ve 0.05 $0.3 \mu \mathrm{mol} / \mathrm{L}(0.002-0.012 \mathrm{mg} / \mathrm{dL})$ dir. $^{14}$ Bitkisel steroller/ stanoller dolaşımda lipoproteinlerde taşınmaktadır. Esas olarak LDL parçacıklarında (\%70-\%80) ve yüksek yoğunluklu lipoprotein parçacıklarında (\%20-\%30) bulunmaktadir. $^{31}$

\section{Bitkisel Sterollerin/Stanollerin Aterosklerotik Süreç ve Kardiyovasküler Hastalıklar Üzerine Etkisi}

Diyetle bitkisel sterol/stanollerinin alımının artırılması, plazma toplam koleterol (TK) ve LDL-K konsantrasyonlarını düşürmek için uygulanabilir müdahalelerden biridir. ${ }^{32}$ Li ve arkadaşları, 18-60 yaş aralığında 912 yetişkin bireyin besinlerle aldıkları bitkisel sterol/stanol miktarı ile beden kütle indeksi, bel çevresi, kan basıncı, serum TK ve LDL-K seviyelerini ters ilişkili bulmuşlardır. ${ }^{33}$ Son çalışmalardan elde edilen bulgular; bitkisel sterollerin bağırsak kolesterolü emilimini (azalmış kolesterol emilimi, artmış fekal kolesterol kaybı) azaltarak ve hepatik kolesterol sentezinde görevli genlerin ifadesini (artan HMG-CoA redüktaz mRNA) değiştirerek kolesterol seviyelerini düşürdügünü vurgulamaktadır. ${ }^{14,34-36}$ Ayrıca, bitkisel sterollerin, 27-hidroksikolesterol üretimi, karaciğer $\mathrm{X}$ reseptörü alfa aktivasyonunun inhibisyonu ve insan kolon adenokarsinoma hücre dizisi (Caco-2) enterositlerinde bazolateral sterol 
taşıyıcısı olan ATP bağlayıcı kaset A1 (ABCA1) ifadesi ile kolesterol emilimini azaltabileceği görüşü de mevcuttur. ${ }^{37}$ Randomize kontrollü çalışmaların yer aldığı bir meta analiz çalışmasında, bitkisel sterollerin/stanollerin TK, LDL-K ve trigliserit (TG) konsantrasyonları üzerinde benzer düşürücü etkileri olduğu bildirilmiştir. ${ }^{38}$ Racette ve arkadaşlarının yaptığı bir çalışmada; 18-80 yaş aralığında 18 bireyin diyetlerine farklı dozlarda bitkisel sterol ilavesi yapılmış ve çalışma sonunda düşük bitkisel sterol alımına göre (59 mg'/gün) orta ve yüksek düzey alımın (459 ve 2059 mg/gün) fekal ve safra kolesterol atılımını sırasıyla $\% 36 \pm 6$ ile $\% 74 \pm 10$ ve $\% 38 \pm 7$ ile $\% 77 \pm 12$ oranında artırdı̆̆ , intestinal kolesterol emilimini önemli ölçüde (\%10 1 ile $\% 25 \pm 3$ ) azalttığı görülmüştür. ${ }^{39}$ Sialvera ve arkadaşlarının yaptığı bir çalışmada; metabolik sendromlu hastalar $(\mathrm{n}=108)$ batı tarzı diyetlerinin yanında $4 \mathrm{~g} /$ gün bitkisel sterol ile zenginleştirilmiş yoğurt bazlı mini içeceği veya bitkisel sterol içermeyen bir yoğurt içeceği 2 ay boyunca almış ve çalışma sonunda zenginleştirilmiş mini içeceği kullanan bireylerin diğer bireylere kıyasla küçük yoğun düşük yoğunluklu lipoprotein (sdLDL), apolipoprotein B (Apo-B) ve TG düzeylerinde anlamlı bir azalma saptanmıştır. Ayrıca, batı tarzı diyete rağmen bitkisel sterol ile zenginleştirilmiş içecek serum TK, LDL-K ve TG düzeylerini sırasıyla \%15.9, \%20.3 ve \%19.1 oranında düşürmüştür. ${ }^{40}$ Güncel başka bir çalışmada ise; yaşları 24-79 arasında değişen sağlıklı gönüllüler $(n=221)$ bitkisel sterol içeren (1.5 g/gün) az yağlı sütü veya bitkisel sterol içermeyen az yağlı sütü üç hafta boyunca tüketmişler ve çalışma sonunda zenginleştirilmiş az yağlı süt alanların serum LDL-K ve TK seviyelerinde (\%9.5 \pm 2.0$)$ anlamlı bir düşüş görülmüştür.41 Bir deney hayvan çalışmasında ise Suriye Golden hamsterine $(\mathrm{n}=80)$ farklı oranlarda $(\% 0.37, \% 0.74$ ve \%1.85 (ağırlık/vücut ağırlık)) bitkisel sterol/stanol karışımı içeren laktik-fermente süt tozu ile birlikte yüksek yağ ve kolesterol diyeti 4 hafta boyunca uygulanmış ve çalışma sonunda \%0.74 ve \%1.85'lük bitksel sterol/stanol alımı fekal kolesterol atımını önemli ölçüde artırarak serum TK, TG, karaciğer lipidleri ve aterojenik indeks seviyelerini önemli ölçüde azaltmıştır. ${ }^{42}$
Avrupa Besin Güvenliği Otoritesi (European Food Safety Authority/EFSA) verilerine göre; en az iki ila üç hafta süreyle bitkisel sterol esterlerinin $3.0 \mathrm{~g} /$ gün düzeyinde alımı, serum LDL-K seviyesini \%11.3 oranında düşürmektedir. ${ }^{43}$ Rideout ve arkadaşları (2010), 6 hafta süre boyunca uygulanan \%2 (ağırlık/vücut ağırlığı) oranında bitkisel sterol desteği ile plazma ve hepatik TG konsantrasyonlarının sırasıyla \%28 ve \%30 oranında daha düşük olduğunu saptamışlardır. ${ }^{44}$ Uzun süreli bitkisel stanol alımını (12 ay boyunca, 2 g/gün) inceleyen bir araştırma da; bitkisel stanollerin hiperkolesterolemili bireylerde LDL-K konsantrasyonlarını önemli ölçüde azalttığı (\%10 ve üzeri) bildirilmiştir. ${ }^{45}$ Amerikan Ulusal Kolesterol Eğitim Programı, hiperkolesterolemili bireylerde terapötik yaşam tarzı değişimi programı ve diyetine $1.8 \mathrm{~g} /$ gün bitkisel sterol/stanol esteri içeren suplemanların dahil edilmesinin aterojenik lipoprotein kolesterol seviyelerini düşürücü değişiklikler yarattığını bildirmiştir. ${ }^{11}$

Bitkisel sterollerin/stanollerin lipid bileşenleri üzerinde olumlu etkilerinin bilinmesine rağmen, arteryel lezyonların gelişimine ya da gerilemesine katkısı olup olmadığı ise halen tartışmalıdır. ${ }^{46,47}$ Ancak bitkisel sterollerin, yüksek kolesterollü diyet ile birlikte alındığında aterosklerotik plak oluşumunu azaltabileceği görüşü mevcuttur. ${ }^{48} \mathrm{Bu}$ görüşü destekler bir biçimde, bitkisel sterollerin arter duvarında birikmediği ve aterosklerozu önlediği bildirilmiştir. ${ }^{49} \mathrm{Bu}$ önleme etkisinin ateroskleroz gelişiminde rolü olabileceği düşünülen ATP bağlayıcı kaset G1'in (ABCG1) mRNA ifadesini aşağı yönlü etkilemesinden ileri gelebileceği düşünülmektedir. ${ }^{49}$ Moghadasian ve arkadaşları (2016), LDL/- transjenik farelerde \%2 (ağırlık/vücut ağırlığı) oranında bitkisel sterol desteğinin kontrol grubundakilere kıyasla aortik köklerdeki aterosklerotik lezyonların büyüklügünü ve şiddetini anlamlı olarak azalttığını saptamıştır. ${ }^{50} \mathrm{Bu}$ etkileri ile ilgili yeterli düzeyde çalışma bulunmamasından dolayı bitkisel sterollerin aterom plaklar üzerine etkisi hala tartışmalıdır ve daha kapsamlı araştırılmasına ihtiyaç vardir. 
Kardiyovasküler hastalıklar gibi metabolizma odaklı patofizyolojik süreçler epigenetik faktörler ile de ilişkilidir. Biyoaktif besin bileșenlerinin, enzim inhibisyonuna ve DNA hiper/hipo metilasyonu gibi epigenetik değişimlere yol açtığı ve böylece gen ifadesinin baskılandığı veya uyarıldığı bildirilmektedir. ${ }^{51}$ Diyet bileşenleri, DNA metilasyon bölgeleri aktivitesini değiştirerek gen ifadesini etkilemektedir. ${ }^{52}$ Bitkisel sterollerin hepatik gen ifadesi ve DNA metilasyonu üzerinde etkisi olabilir. Ancak metabolik yolaklarda ve DNA düzeyinde yol açtığı değişikliklere yönelik bilgiler hala netlik kazanmamıştır. Bilinen etkisi; hepatik kolesterol sentezinde görevli genlerin ifadesini (artan HMG-CoA redüktaz mRNA) değiştirerek kolesterolü düşürmektir. ${ }^{14,34-36}$ Ayrıca, ABCA1 ve ABCG1 bolluğu, kolesterol akışı ve inflamatuar sitokin sekresyonu gen ifadeleri üzerindeki etkileri, kültürlenmiş makrofaj köpük hücrelerinde görülmüştür. ${ }^{53}$ Mevcut bilgilerle gen ifadesi üzerinde etkisi hakkında yargıya varmak güçtür. Epigenetik ve nutrigenetik temelli daha fazla çalışmanın yapılması bu konunun aydınlatılması adına yararlı olacaktır.

Bitkisel sterollerin ve stanollerin aterosklerotik süreç ve lipid profili üzerine etkisini araştıran 1997-2018 yılları arasında yapılan çeşitli literatür çalışmaları Tablo-1 ve Tablo 2'de özetlenmiștir. ${ }^{45,49,50,54-80}$ Tablo-1'de yer alan hiperkolesterolemili yetişkin bireylere farklı doz, süre ve uygulamalarla verilen bitkisel sterol ve stanollerin özellikle TK ve LDL-K seviyelerini anlamlı ölçüde düşürdüğü görülmüştür. Bitkisel sterol esteri ile stanol esterinin TK ve LDL-K seviyeleri üzerinde etkinliği ise oldukça benzerdir. Bitkisel sterol ve stanol türevlerinin TK ve LDL-K seviyeleri üzerinde olumlu etkilerine rağmen, TG ve HDL-K seviyelerinde anlamlı bir farklılığa neden olmadığı görülmektedir. Tablo-2'de yer alan deney hayvan çalışmalarından elde edilen bilgiler ile farklı doz, süre ve uygulamalarla verilen bitkisel sterollerin/stanollerin LDL-K ve TK seviyelerini düşürdüğü, kolesterol emilimini azalttığı, kolesterol atımını artırdığı, makrofaj alanını küçülttüğü ve aterosklerotik lezyonları sınırladığı söylenebilir.
Bitkisel sterollerin lipoprotein metabolizmasında olduğu gibi inflamatuar yolaklarda da antiaterojenik etkileri bulunmaktadır. ${ }^{81}$ Bitkisel steroller, inflamutuar uyarıcılara tepki olarak proinflamatuar sitokinlerin ve kemokinlerin kapasitesinde azalmaya neden olmakla birlikte anti-inflamatuar sitokinlerin üretimini desteklemektedir. Bahsi geçen etki mekanizması ile bitkisel steroller, immün sistem fonksiyonlarının regülasyonuna katkı sağlayarak inflamatuar sürecin önlemesinde rol oynamaktadır. ${ }^{81}$ Ayrıca, aterosklerozun patogenezinde etkin rolü olan plazma fibrinojen seviyelerini azaltarak antiaterojenik ve trombosit seviyelerini düşürerek antitrombotik etki göstermektedir. ${ }^{82}$ Bunun yanı sıra, tümör nekroz faktör-alfa (TNF- $\alpha$ ) ve interlökin-6 (IL-6) seviyelerini indirgeyip interlökin-10 (IL-10) seviyelerini on kat artırarak antiinflamatuar ve antiaterojenik rol üstlenmektedir. Bitkisel sterollerce zengin bir diyetin, daha yüksek anti-iflamatuar IL-10 seviyeleri, daha düşük proinflamatuar sitokin (IL-6, TNF- $\alpha$ ) seviyeleri ve düşük plazma kolesterol konsantrasyonları ile ilişkili olduğu saptanmıştır. ${ }^{81}$ Bitkisel sterollerin, makrofaj köpük hücrelerinde lipid yüklemesine yanıt olarak kolesterol ak1şını hızlandırdığı ve inflamasyonlu sitokin sekresyonunu bastırdığı belirtilmektedir..$^{53}$

Avrupa Ateroskleroz Derneği ve Amerikan Ulusal Kalp Akciğer ve Kan Enstitüsü (NHLBI) Ulusal Kolesterol Eğitim Programı 2 g/gün miktarında bitkisel sterollerin/ stanollerin serum lipid profilleri üzerinde olumlu etkileri nedeniyle diyete ilave edilmesini önermektedir. ${ }^{89}$ Avrupa Kardiyoloji Derneği, 2016 yılına ait kardiyovasküler hastalıklardan korunma kılavuzunda bitkisel sterol ve stanollerin $2 \mathrm{~g}$ /gün düzeyinde tüketildiğinde LDL-K seviyesini ortalama \%10 düşürdüğünü belirtmiştir. ${ }^{83}$ Kolesterol seviyelerini düşürmek amaciyla optimal olarak kabul edilen günlük alım miktarı bitkisel sterollerin/stanollerin 2-3 gramıdır. ${ }^{84}$ AHA, 2007 yılına ait Kronik Kararlı Angina Rehberinde, LDL-K seviyelerinin azaltılmasına yardımcı olmak için bitkisel stanoller/steroller veya viskoz lifi ilavesinin önemli olacağını bildirmiştir. ${ }^{85}$ Bununla birlikte, AHA bitkisel steroller/stanoller ile zenginleştirilmiş 
Sakarya Tip Dergisi 2019;9(2):218-229

ÇEKícì ve Ark., Bitkisel Steroller/Stanoller ve Kardiyovasküler Sağllk

\begin{tabular}{|c|c|c|c|c|}
\hline Yazar & Yil & Örneklem & Doz - Süre & Sonuç \\
\hline Nestel vd..$^{54}$ & 2001 & 22 & BS esteri ( $2.4 \mathrm{~g} /$ gün) veya stanol esteri ( $2.4 \mathrm{~g} / \mathrm{gün})-4$ hafta & LDL-K seviyeleri, BS esterleri ile \%13.6, stanol ile $\% 8.3$ oranında azalmıștır. \\
\hline Nestel vd. ${ }^{54}$ & 2001 & 15 & $\% 50$ süt yağı veya $\% 50$ süt yağı + BS esteri ( $2.4 \mathrm{~g} / \mathrm{gün})$ - 4 hafta & $\begin{array}{l}\text { LDL-K seviyeleri süt yağı ile } \% 6,5 \text { düzeyinde artış gösterirken, BS esteri } \\
\text { takviyesi ile } \% 12,2 \text { düzeyinde düşmüștür. }\end{array}$ \\
\hline $\begin{array}{l}\text { De Graaf } \\
\text { vd. }{ }^{55}\end{array}$ & 2002 & 70 & $\begin{array}{l}\text { BS ( } 1.8 \mathrm{~g} / \text { gün esterlenmemiş) ilaveli çikolata veya düşük yağlı kolesterollü } \\
\text { diyet ile plasebo çikolata - } 4 \text { hafta }\end{array}$ & $\begin{array}{l}\text { BS ile zenginlesstirilmiş çikolata ile plazma TK ve LDL-K düzeyleri sırasıyla } \\
\% 6.4 \text { ve } \% 10.3 \text { düzeyinde azalmıştır. }\end{array}$ \\
\hline $\begin{array}{l}\text { Noakes } \\
\text { vd. }{ }^{56}\end{array}$ & 2002 & 46 & $\begin{array}{l}\text { Sterol içermeyen sürülebilir yağ }(25 \mathrm{~g} / \mathrm{gün}) \text { veya BS esteri }(2.3 \mathrm{~g}) \text { içeren veya } \\
\text { bitkisel stanol esteri }(2.5 \mathrm{~g}) \text { içeren yağ }-3 \text { hafta }\end{array}$ & $\begin{array}{l}\text { BS ester ve bitkisel stanol ester tüketiminden sonra LDL-K seviyeleri sırasıy- } \\
\text { la } \% 7.7 \text { ve } \% 9.5 \text { oranında azalmıștır. }\end{array}$ \\
\hline $\begin{array}{l}\text { O'Neill } \\
\text { vd. }{ }^{57}\end{array}$ & 2004 & 134 & $\begin{array}{l}\text { BS esteri }(1.6 \mathrm{~g} / \mathrm{gün}) \text { içeren margarin }+1 \text { plasebo tahıl barı veya bitkisel } \\
\text { stanol esteri }(1.6 \mathrm{~g} / \text { gün }) \text { içeren margarin }+1 \text { plasebo tahıl barı veya bitkisel } \\
\text { stanol esteri }(1.6 \mathrm{~g} / \text { gün }) \text { içeren margarin }+1.0 \mathrm{~g} \text { stanol esteri içeren tahıl } \\
\text { barı - } 8 \text { hafta }\end{array}$ & $\begin{array}{l}\text { Sterol ve stanol esterlerinin farklı uygulamalarının TK (\%3-7) ve LDL-K } \\
\text { (\%4-8) seviyelerini düşürmede farklı olmadığı görülmüştür. }\end{array}$ \\
\hline Hansel vd. ${ }^{58}$ & 2007 & 194 & $\begin{array}{l}\text { BS esteri içeren }(1.6 \mathrm{~g}) \text { zenginleștirilmiş fermente süt veya BS içermeyen } \\
\text { fermente süt - } 6 \text { hafta }\end{array}$ & $\begin{array}{l}\text { BS esteri okside LDL-K'nın plazma konsantrasyonunu önemli derecede } \\
\text { düşürmüsstür. Plazma LDL-K düzeylerini } 3 \text {. ve } 6 \text { haftada sırasıyla } \% 9,5 \text { ve } \\
\% 7,8 \text { oranında düşürmüştür. }\end{array}$ \\
\hline Li vd. ${ }^{59}$ & 2007 & 309 & BS esteri ( $2.3 \mathrm{~g}$ veya $1.5 \mathrm{~g}$ ) ile zenginleştirilmiş süt tozu veya plasebo - 5 hafta & $\begin{array}{l}\text { BS’nin } 2.3 \mathrm{~g} / \text { gün düzeyinde alımı, TK konsantrasyonunda } 0.25 \mathrm{mmol} / \mathrm{L} \\
\text { düzeyinde, } 1.5 \mathrm{~g} / \text { gün düzeyinde alımı ise } 0.23 \mathrm{mmol} / \mathrm{L} \text { düzeyinde anlamlı } \\
\text { bir azalmaya neden olmuștur. }\end{array}$ \\
\hline $\begin{array}{l}\text { De Jong } \\
\text { vd. }{ }^{60}\end{array}$ & 2008 & 45 & $\begin{array}{l}\text { Margarin tüketimi ( } 4 \text { hafta) sonrası, margarin veya BS esteri/stanol esteri } \\
(2.5 \text { g/gün) ile zenginleștirilmiş margarin - } 16 \text { hafta }\end{array}$ & $\begin{array}{l}\text { BS ve stanol margarini LDL-K konsantrasyonlarında istatistiksel olarak an- } \\
\text { lamlı bir azalmaya neden olmuştur. }\end{array}$ \\
\hline $\begin{array}{l}\text { Mannarino } \\
\text { vd. }{ }^{61}\end{array}$ & 2009 & 116 & $\begin{array}{l}\text { Fermente süt ürünü veya BS esteriyle (1.6 g/gün) zenginleștirilmiş fermente } \\
\text { süt - } 6 \text { hafta }\end{array}$ & $\begin{array}{l}\text { BS esteriyle zenginleștirilmiş fermente süt, LDL-K konsantrasyonunu } \\
166.2 \pm 2.0^{\prime} \mathrm{dan} 147.4 \pm 2.8 \mathrm{mg} / \mathrm{dL} \text { 'ye, TK seviyelerini ise } 263.5 \pm 2.6^{\prime} \text { dan } \\
231.0 \pm 3.2 \mathrm{mg} / \mathrm{dL} \text { 'ye düşürmüștür. }\end{array}$ \\
\hline Bañuls vd. ${ }^{62}$ & 2011 & 75 & Standart sağlıklı beslenme ( 3 ay) sonrası $2 \mathrm{~g} / \mathrm{gün}$ BS + diyet veya diyet -6 ay & $\begin{array}{l}\text { BS, TK ve LDL-K seviyelerinde sırasılyla } \% 5.1 \text { ve } \% 8.1 \text { oranında düșüşe ve } \\
\text { Apo B-100/Apo A-I oranında anlamlı bir azalmaya neden olmuştur. }\end{array}$ \\
\hline $\begin{array}{l}\text { Vásquez- } \\
\text { Trespalacios } \\
\text { vd.63 }\end{array}$ & 2014 & 40 & $\begin{array}{l}\text { Standart yoğurt içeceği veya bitkisel stanol esteri eklenmiş ( } 4 \mathrm{~g} \text { ) yoğurt } \\
\text { içeceği - } 4 \text { hafta }\end{array}$ & $\begin{array}{l}\text { Bitkisel stanol esteri içeren yoğurt içeceği, TK ve LDL-K seviyelerinde } \\
\text { sırasıyla } \% 7,2 \text { ve } \% 10,3 \text { oranında düşusşe neden olmuștur. }\end{array}$ \\
\hline Jacobs vd. ${ }^{64}$ & 2015 & 282 & $\begin{array}{l}\text { BS ( } 2.5 \mathrm{~g} / \mathrm{gün}) \text { içeren sürmelik yağ veya sade sürmelik yağ veya farklı do- } \\
\text { zlarda EPA + DHA (0.0, } 0.9,1.3 \text { ve } 1.8 \mathrm{~g} \text { / gün) içeren sürmelik yağ - } 4 \text { hafta }\end{array}$ & $\begin{array}{l}\text { BS alımı ile LDL-K seviyelerinde azalma görülmüștür. BS içeren yağa EPA + } \\
\text { DHA'nın eklenmesi doza bağlı olarak VLDL ve TG seviyelerini azaltmıștır. }\end{array}$ \\
\hline $\begin{array}{l}\text { Kietsiriroje } \\
\text { vd. }{ }^{65}\end{array}$ & 2015 & 240 & $\begin{array}{l}\text { BS ( } 2 \mathrm{~g} / \text { gün) ile zenginleștirilmiş soya sütü veya inülinle ( } 10 \mathrm{~g} / \mathrm{gün}) \text { zengin- } \\
\text { leștirilmiş soya sütü veya standart soya sütü - } 8 \text { hafta }\end{array}$ & $\begin{array}{l}\text { BS ile zenginleştirilmiş soya sütü alımı diğer alımlara kıyasla LDL-K ve TK } \\
\text { konsantrasyonunda sırasıyla } \% 10 \text { ve } \% 6.6 \text { oranında azalma ile en iyi sonuç } \\
\text { vermiştir. }\end{array}$ \\
\hline Padro vd. ${ }^{66}$ & 2015 & 32 & $\begin{array}{l}\text { BS }(1.57 \mathrm{~g}) \text { ile zenginleştirilmiş süt veya } 375 \mathrm{mg} \text { omega- } 3(\mathrm{EPA}+\mathrm{DHA}) \text { ile } \\
\text { zenginleştirilmiş süt - iki ardışı } 28 \text { gün }\end{array}$ & $\begin{array}{l}\text { BS içeren süt, omega-3 içeren süte kıyasla LDL-K seviyelerinde daha yüksek } \\
\text { bir oranda azalmaya neden olmuştur. Ayrıca, BS ile LDL-K'nın oksidasyona } \\
\text { direnci anlamlı olarak artmıştır. }\end{array}$ \\
\hline $\begin{array}{l}\text { Párraga- } \\
\text { Martínez } \\
\text { vd. }{ }^{45}\end{array}$ & 2015 & 182 & $\begin{array}{l}\text { Bitkisel stanol ( } 2 \text { gr/gün) içeren bir yoğurt içeceği veya sade yoğurt içeceği } \\
-12 \text { ay }\end{array}$ & $\begin{array}{l}\text { Stanol verilen grubun, LDL-K düzeyleri anlamlı şekilde daha düşük (13.7 } \\
\text { mg/dL) bulunmuştur. Bitkisel stanol hiperkolesterolemili bireylerde LDL-K } \\
\text { seviyelerini >\%10'dan fazla azaltmıștr. }\end{array}$ \\
\hline Ras vd. ${ }^{67}$ & 2015 & 240 & $\begin{array}{l}\text { Az yağlı sürmelik yağ ( } 20 \mathrm{~g} / \text { gün }) \text { veya BS içeren ( } 3 \mathrm{~g} / \mathrm{gün}) \text { az yağlı sürmelik } \\
\text { yağ - } 12 \text { hafta }\end{array}$ & $\begin{array}{l}\text { BS alımı, akışa bağlı dilatasyonu, arteriyel sertlik (nabız dalga hızı ve aug- } \\
\text { mentation indeksi) ve kan basıncını etkilemezken, LDL-K seviyesini \% } 6.7 \\
\text { oranında önemli ölçüde azaltmıștır. }\end{array}$ \\
\hline Dong vd. ${ }^{68}$ & 2016 & 170 & $\begin{array}{l}\text { Soya sütü tozu veya BS esterleri }(3.4 \mathrm{~g}) \text { ile zenginleștirilmiş soya sütü tozu } \\
-6 \text { ay }\end{array}$ & $\begin{array}{l}\text { BS alımı ile serum TK, LDL-K ve non-HDL-K seviyeleri sırasıyla \%9,3, } \\
\% 11,4 \text { ve } \% 12,6 \text { oranında azalmıştır. }\end{array}$ \\
\hline Ras vd ${ }^{69}$ & 2016 & 240 & Az yağlı sürmelik yağ veya BS (3g/gün) içeren az yağlı sürmelik yağ - 12 hafta & $\begin{array}{l}\text { BS alımı serum LDL, TK, HDL ve TG seviyelerini önemli derecede etkile- } \\
\text { memiștir. }\end{array}$ \\
\hline Zhu vd. ${ }^{70}$ & 2016 & 157 & $\begin{array}{l}\text { BS ( } 1.58 \mathrm{~g} / \text { gün) ile zenginleștirilmiş süt veya BS içermeyen normal süt (500 } \\
\text { mg) veya süt ürünleri içermeyen bir beslenme şekli - } 2 \text { ay }\end{array}$ & $\begin{array}{l}\text { BS alımı TK ve LDL-K seviyelerini anlamlı derecede düşürmüștür ancak TG } \\
\text { ve HDL-K seviyelerinde anlamlı bir farklılı̆ga neden olmamıştır. }\end{array}$ \\
\hline Cicero vd. ${ }^{71}$ & 2017 & 90 & $\begin{array}{l}\text { BS }(800 \mathrm{mg} / \text { gün }) \text { veya monacolin }(5 \mathrm{mg}) \text { içeren standart kırmızı maya pirinç } \\
\text { veya } 800 \mathrm{mg} / \text { gün BS + monacolin }(5 \mathrm{mg}) \text { içeren kırmızı maya pirinç - } 8 \text { hafta }\end{array}$ & $\begin{array}{l}\text { Kırmızı maya pirinci LDL-K seviyesini } \% 20.5 \text {, ApoB seviyesini } \% 14.4 \\
\text { düzeyinde düşürmüsțür. BS ve kırmızı maya pirincinin kombinasyonu } \\
\text { LDL-K düzeyini } \% 27 \text { oranında, ApoB seviyesini ise } \% 19 \text { oranında } \\
\text { düşürmüştür. }\end{array}$ \\
\hline $\begin{array}{l}\text { Ferguson } \\
\text { vd. }^{72}\end{array}$ & 2018 & 76 & $\begin{array}{l}\text { BS ( } 2 \mathrm{~g} / \text { gün }) \text { veya kurkumin ( } 200 \mathrm{mg} / \text { gün }) \text { veya BS + kurkumin ( } 2 \mathrm{~g} / \text { gün } \\
\text { BS- } 200 \mathrm{mg} / \text { gün kurkumin }) \text { - } 4 \text { hafta }\end{array}$ & $\begin{array}{l}\text { BS, TK ve LDL-K seviyelerini sırasıyla } \% 4.8 \text { ve } \% 8.1 \text { oranında düşürürken, } \\
\text { BS-kurkumin kombinasyonu ise TK ve LDL-K seviyelerini sırasıyla } \% 11 \text { ve } \\
\% 14.4 \text { oranında düşürmüştür. }\end{array}$ \\
\hline \multicolumn{5}{|c|}{$\begin{array}{l}\text { Kısaltmalar: BS: bitkisel sterol, LDL-K: düşük yoğunluklu lipoprotein kolesterol, TG: trigliserit, TK: total kolesterol, sdLDL: küçük yoğun düşük yoğunluklu lipoprotein, ApoB-100: apolipo- } \\
\text { protein B-100, Apo A-I: apolipoprotein A-I, AST: aspartat aminotransferaz, ALT: alanin aminotransferaz, TNF-a: tümör nekroz faktör alfa, HDL-K: yüksek yoğunluklu lipoprotein kolesterol, } \\
\text { non-HDL-K: yüksek yoğunluklu olmayan lipoprotein kolesterol, VLDL: çok düşük yoğunluklu lipoprotein, EPA: eikozapentaenoik asit, DHA: dokozahekzaenoik asit }\end{array}$} \\
\hline
\end{tabular}


Sakarya Tip Dergisi 2019;9(2):218-229

ÇEKİĊ ve Ark., Bitkisel Steroller/Stanoller ve Kardiyovasküler Sağlık

\begin{tabular}{|c|c|c|c|c|}
\hline Yazar & Yil & $\begin{array}{l}\text { Hayvan türü - } \\
\text { Örneklem Sayısı }\end{array}$ & Doz - Süre & Bulgular ve Sonuç \\
\hline $\begin{array}{l}\text { Moghada- } \\
\text { sian vd. }{ }^{73}\end{array}$ & 1997 & $\begin{array}{l}\text { Apo-E-/- knock-out } \\
\text { fareler, } n=9\end{array}$ & $\begin{array}{l}\text { BS (\%2 ağırlık/vücut ağırlık)+ standart diyet veya } \\
\text { standart diyet - } 18 \text { hafta }\end{array}$ & $\begin{array}{l}\text { BS verilen farelerde plazma TK seviyelerinin önem- } \\
\text { li ölçüde azaldığı, aort sinüslerindeki lezyon alanının } \\
\text { daha küçük olduğu saptanmıştır. }\end{array}$ \\
\hline $\begin{array}{l}\text { Yeganeh } \\
\text { vd. }{ }^{74}\end{array}$ & 2005 & $\begin{array}{l}\text { Apo-E-/- knock-out } \\
\text { fare, } \mathrm{n}=31\end{array}$ & $\begin{array}{l}\text { KD veya } K D+B S \text { veya } K D+B S+\text { niasin veya } K D+B S+ \\
\text { fenofibrat }-12 \text { hafta }\end{array}$ & $\begin{array}{l}\text { BS plazma TK seviyelerini ve aterosklerozun boyutunu/ } \\
\text { alanını }(0.42 \text { 'ye karşı } 0.15 \mathrm{~mm} 2) \text { önemli ölçüde azalt- } \\
\text { mıştır. BS+niasin ise sinerjik olarak HDL-K seviyelerini } \\
\text { artırmıştır. }\end{array}$ \\
\hline Brufau vd. ${ }^{75}$ & 2011 & $\begin{array}{l}\text { Abcg5-/- fare } \\
\text { Vahşi tip fare }\end{array}$ & $\begin{array}{l}\text { Vahşi tip fareler KD veya } \mathrm{KD}+\mathrm{BS}(\% 1, \% 2, \% 4, \% 8 \\
\text { ağırlık/vücut ağırlık) - } 2 \text { hafta } \\
\text { Abcg5-/- fareler KD veya } \% 8 \mathrm{BS}+\mathrm{KD} \text { - } 2 \text { hafta }\end{array}$ & $\begin{array}{l}\text { BS, vahşi tip farelerde doza bağlı fraksiyonel kolester- } \\
\text { ol emiliminin azalmasına (yaklaşı } 2-7 \text { kat), Abcg5- } \\
\text { /- farelerde } \% 80 \text { oranında azalmasına yol açmıştır. BS, } \\
\text { intestinal kolesterol atılımını vahşi tip farelerde } \% 500 \text {, } \\
\text { Abcg5-/- farelerde ise } \% 250 \text { oranında uyarmıștır. }\end{array}$ \\
\hline \multirow[t]{2}{*}{ Vahşi tip fare } & 2013 & $\begin{array}{l}\text { Sprague-Dawley } \\
\text { erkek rat, } n=60\end{array}$ & $\begin{array}{l}\text { Probiyotik (1010-11 cfu, } 5 \mathrm{~mL})+25 \mathrm{mg} / \mathrm{gün} \text { BS veya } \\
\text { plasebo }\end{array}$ & $\begin{array}{l}\text { Karışım supleman desteği serum TK, LDL-K ve TG se- } \\
\text { viyelerini önemli ölçüde azaltmıștır. }\end{array}$ \\
\hline & 2013 & $\begin{array}{l}\text { LDLr knock-out } \\
\text { fare, } n=20\end{array}$ & $\begin{array}{l}\text { BS ilaveli (\%2 ağırlık/vücut ağırlık) veya ilavesiz } \\
\text { YYD (\%40 yağ) - } 16 \text { hafta }\end{array}$ & $\begin{array}{l}\text { BS grubunda aterosklerotik lezyon ve makrofaj alanı } \\
\text { kontrol grubundan daha küçük bulunmuștur. }\end{array}$ \\
\hline $\begin{array}{l}\text { Abcg5-/- } \\
\text { fareler KD } \\
\text { veya } \% 8 \\
\text { BS+KD - } 2 \\
\text { hafta }\end{array}$ & 2014 & $\begin{array}{l}\text { C57BL/6J erkek fare, } \\
\mathrm{n}=18\end{array}$ & $\begin{array}{l}\text { YYD veya BS esteri (\%3.1 ağırlık/vücut ağırlık)+YYD } \\
\text { veya stanol esteri (\%3.1 ağırlık/vücut ağırlık)+YYD - } \\
3 \text { hafta }\end{array}$ & $\begin{array}{l}\text { BS esteri ve bitkisel stanol esteri hepatik kolesterol se- } \\
\text { viyelerini düşürmüştür ve VLDL'nin salınımını azalt- } \\
\text { mıştır. }\end{array}$ \\
\hline $\begin{array}{l}\text { Awaisheh } \\
\mathrm{vd}^{76}\end{array}$ & 2015 & $\begin{array}{l}\text { LDLr knock-out } \\
\text { erkek fare, } n=40\end{array}$ & $\begin{array}{l}\text { BS-Echium yağı kombinasyonu (insan 2g/gün BS’ye } \\
\text { denk gelen doz) - } 4 \text { ay }\end{array}$ & $\begin{array}{l}\text { Karışım kombinasyonu, GSH-Px aktivitesini artırırken, } \\
\text { karaciğer MDA konsantrasyonunu azaltmıştır. }\end{array}$ \\
\hline Bombo vd. ${ }^{49}$ & 2016 & $\begin{array}{l}\text { Suriye golden ham- } \\
\text { ster, } \mathrm{n}=50\end{array}$ & $\begin{array}{l}\text { D-linolenik asit }+ \text { BS esterleri }(\% 0.72, \% 2.13 \text {, } \\
\% 6.39)+ \text { YYD - } 6 \text { hafta }\end{array}$ & $\begin{array}{l}\text { 叉-linolenik asit+BS esterleri, doz bağımlı olarak TK, } \\
\text { TG ve LDL-K seviyelerini sırasıyla } \% 42, \% 59 \text { ve } \% 73 \\
\text { oranında düşürmüştür. }\end{array}$ \\
\hline $\begin{array}{l}\text { Schonewille } \\
\text { vd. }{ }^{77}\end{array}$ & 2016 & $\begin{array}{l}\text { LDLr knock-out } \\
\text { erkek fare, } \mathrm{n}=32\end{array}$ & $\begin{array}{l}\text { KD veya \%60 (ağırlık/vücut ağırlık) yabani pir- } \\
\text { inç+KD veya \%2 (ağırlık/vücut ağırlık) BS+KD veya } \\
\text { yabani pirinç+\%2 (ağırlık/vücut ağırlık) BS+KD - } 20 \\
\text { hafta }\end{array}$ & $\begin{array}{l}\text { KD grubunda aort kökünde ilerlemiş aterosklerotik } \\
\text { lezyonlar görülürken, tek başına yabani pirinç veya } \\
\text { tek başına BS alan grup sınılı ölçüde lezyon tutulu- } \\
\text { mu göstermiştir. Yabani pirinç + BS grubunun aortik } \\
\text { kökleri lezyonlardan neredeyse yoksundur. BS grubu } \\
\text { en düşük aterojenik indeks oranına sahip bulunmuştur. }\end{array}$ \\
\hline Botelho vd. ${ }^{78}$ & 2017 & $\begin{array}{l}\text { C57BL/6J, Apo-E-/- } \\
\text { knock-out ve } \\
\text { LXRa } \beta \text {-eksik fare }\end{array}$ & $\begin{array}{l}\text { BTD (\%21 yağ, } \% 0.2 \text { kolesterol ve }<\% 0.01 \mathrm{BS}) \text { veya } \\
\% 2 \text { BS+BTD veya BTD+ ezetimibe }(\% 0,005)-4 \text { haf- } \\
\text { ta }\end{array}$ & $\begin{array}{l}\mathrm{BS} \text {, hem C57BL/6J hem de LXRa } \beta \text {-eksikliği olan } \\
\text { farelerde bağırsak kolesterol emiliminin yaklaşık \% } 40 \\
\text { oranında azalmasına, karaciğerde diyet kolesterol biri- } \\
\text { kiminin azalmasına ve dıșkı ile kolesterol atılımının } \\
\text { artmasına neden olmuştur. }\end{array}$ \\
\hline
\end{tabular}

ürünlerin düzenli tüketiminin güvenliğini sağlayan uzun süreli takip çalışmasının yeterli sayıda olmadığını vurgulamaktadır. ${ }^{86}$ Birleşik Krallık Ulusal Sağlık ve Klinik Mükemmellik Enstitüsünün güncellenmiş yönergeleri bitkisel sterollerin/stanollerin bir besin takviyesi olarak alınmamasına yönelik tavsiyede bulunmaktadır. ${ }^{87}$ EFSA, kolesterol LDL-K seviyelerini düşürmek için günlük olarak $3 \mathrm{~g}$ (2.6-3.4 g) sterol/stanol esterlerinin kullanımını 375/2010 sayılı tüzük (süt ürünleri, mayonez ve salata sosları) (EC) ile onaylamıştır. ${ }^{43}$ Amerikan Gıda ve İlaç Dairesi, bitkisel sterol/stanol esteri tüketimi ile ilgili sağlık beyanında" sterol/stanol esteri tüketmek, koroner kalp hastalığı riskini azaltabilir " bulunulmasına onay vermiştir ve onayı günümüzde de geçerlidir. ${ }^{88,89}$

Bitkisel sterollerin/stanollerin besinlerde sınırlı düzeyde bulunması ve emilimlerinin oldukça düşük olması sebebi ile alışılagelmiş diyetimizle önerilen miktara ulaşmak mümkün değildir. Günümüzde farklı miktarlarda sterol ve stanol ile zenginleştirilmiş pek çok ürün dünya piyasasında yerini almıştır. Margarinler bunlar içinde en çok kullanılanıdır. Serbest haldeki bitki sterollerinin/stanolle- 
rinin kolesterol düşürücü etkilerinin esterlenmiş ürünler ile benzer olduğu bulunduktan sonra hazır portakal suyu, az yağlı süt ürünleri, kek, kruvasan gibi ürünlere de stanoller/steroller ilave edilmiştir. ${ }^{32,54}$ Bunlar dışında yoğurt, krem peynir, tereyağ gibi besinlerde de sıklıkla kullanılmaktadır. ${ }^{90}$ Avrupa Birliği’nde (27 ülke), bitkisel steroller/ stanoller ve bunların esterlerinin gidalardaki kullanımı, Avrupa Parlamentosu 27 Ocak 1997 tarihli Konseyinde, (EC) 258/97 nolu düzenleme ile belirlenmiştir. ${ }^{91}$ Bitkisel sterol/stanol türevlerinin ilk onayı 2000 yılında verilmiştir. 2008 yılına kadar, farklı besin türleri (margarin, salata sosu, süt ürünleri, fermente süt ürünleri, yoğurt ürünleri, süt bazlı meyve içecekleri, süt bazlı içecekler, soya içecekleri, pirinç içecekleri, peynir ürünleri, baharatlı soslar, tahıl bazlı ürünler ve çavdar ekmeği) için çeşitli onaylar verilmiştir. ${ }^{84}$ Ülkemizde, 26 Ocak 2017 tarihinde 29960 sayılı Resmi Gazete'de yayımlanan Türk Gıda Kodeksi Beslenme ve Sağlık Beyanları Yönetmeliğinin Hastalık Riskinin Azaltılmasına İlişkin Sağlık Beyanları Listesinde bitkisel steroller/stanoller ile ilgili sağlık beyanı koşulları detaylı bir şekilde açıklanmıştır. ${ }^{92}$

Bitkisel sterollerin/stanollerin in vitro mutajenik aktivitesi ya da subkronik toksisitesi bulunmamaktadır. Ayrıca, herhangi bir östrojenik etkisi görülmemiştir. ${ }^{11}$ Randomize kontrollü bir çalışmada; 4 hafta süresince çeşitli miktarlarda (3g/gün, 6 g/gün ve 9 g/gün) bitkisel stanol içeren margarin ve yoğurtları tüketen bireylerde önemli bir yan etkinin görülmediği belirtilmiştir. ${ }^{93}$ Bitkisel steroller/stanoller düşük düzeylerde emilim sergilediği ve kalanı boşaltım sisteminde bekletilmeden atıldığı için toksikolojik bir etkinin söz konusu olmadığı belirtilmektedir. ${ }^{94}$ Bitkisel sterollerin/stanollerin hepatik fonksiyonlara ve hormonal seviyelere yönelik herhangi bir olumsuz etkisi bulunmamaktadır. Ancak, birtakım yağda çözünebilen vitaminlerin (A vitamini, E vitamini) emilimine yönelik olumsuz etkileri olabilmektedir. ${ }^{11}$ Serum tokoferol, $\beta$-karoten ve a-karoten konsantrasyonlarında sirasıyla \%8, \%25 ve $\% 10$ düzeylerinde azalmalara neden olabileceği bildirilmiştir. ${ }^{95}$ Bitkisel steroller/stanoller hakkındaki mevcut bilimsel ka- nıtlar, aşırı alımının kandaki karotenoid düzeyini düşürdügünü göstermiştir. Dolayısıyla 3 g/gün üzerindeki alımlar önerilmemektedir. ${ }^{96}$ Bitkisel sterol ile zenginleştirilmiş ürünlerin, yeterli karoten alımını sağlamak için meyve ve sebze içeren dengeli bir diyetin bir parçası olarak tüketilmesi tavsiye edilmektedir. ${ }^{96}$ Bitkisel sterollerin/stanollerin, 2 ila 5 yıl gibi uzun süreyle alınması, kolesterol düşürücü etkinin sürdürülebilmesi ve kardiyovasküler hastalıkların olumsuz sonuçlarını önlemek için önemlidir. ${ }^{97}$

Bitkisel sterol/stanol suplemanı ile besinlerden alınan bitkisel sterollerin/stanollerinin etkinliğini doğrudan karş1laştıran yeterli sayıda çalışma yoktur. Ancak, LDL-K seviyelerini düşürme etkinliğinin değerlendirildiği mevcut bir çalışmada; bitkisel steroller/stanoller suplemanı ile bitkisel steroller/stanoller ile zenginleştirilmiş besinler arasında anlamlı bir fark olmadığ görülmüştür. ${ }^{46}$ Ayrıca, Amerikan Sağlık Bakanlığg ve Amerikan Kalp Derneği, A vitamini seviyelerini etkileyebilme olasılığından dolayı, gebelerde ve küçük çocuklarda bitkisel sterol suplemanlarının kullanılmamasına yönelik tavsiyede bulunmuştur. ${ }^{98}$

\section{SONUÇ}

Bitkisel sterollerce/stanollerce zengin bir diyetin, hem hiperkolesterolemik lipid seviyelerini düşürerek hem de aterosklerozun metabolik sürecinde antiinflamutuar etki göstererek sağlığın korunmasında etkin rol oynayabileceği görülmektedir. Elde edilen veriler, dünyada en yüksek mortalite oranına sahip kalp-damar hastalıklarının patofizyolojik süreci olan aterosklerozun önlemesinde diyetsel müdahalelere yön verebileceğinden dolayı önemlidir. Bitkisel sterol/stanollerin serum lipid profilleri ve aterom plaklar üzerine etkilerinin araştırılmasının beraberinde, bütüncül bir yaklaşımla lipid ile ilintili gen ifadelerinin değişimi üzerine olası etkisinin araştırılması oldukça önemlidir. 
Sakarya Tip Dergisi 2019;9(2):218-229

ÇEKİCİ ve Ark., Bitkisel Steroller/Stanoller ve Kardiyovasküler Sağlık

\section{Kaynaklar}

1. Tanriverdi B, Tetik Savas S. Atherosclerosis pathophysiology and risk factors. Marmara Pharm J 2017; 21:1-9.

2. Türk Kardiyoloji Derneği. Koroner kalp hastalğı korunma ve tedavi kılavuzu. Erişim adresi: http://www.tkd.org.tr/kilavuz/k11.htm. Erişim tarihi: 02.07.2018.

3. Onat A. TEKHARF 2017 Tip Dünyasının Kronik Hastalılara Yaklaşımına Öncülük. 1 . baskı. İstanbul: Logos Yayıncllk Tic. A.Ș; 2017. s: 20-25.

4. Türkiye İstatistik Kurumu. 2018 ölüm nedeni istatistikleri. Haber bülteni, Sayl: 30626. Erişim adresi: http://tuik.gov.tr/PreHaberBultenleri.do?id=30626. Erişim tarihi: 24.05 .2019$.

5. Zengin H. Pathogenesis of atherosclerosis. J Exp Clin Med 2012; 29: 101-106.

6. Tokgözoğlu L. Atherosclerosis and the role of inflammation. Arch Turk Soc Cardiol 2009; 37(4):1-6.

7. Ordovas JM. Genetic influences on blood lipids and cardiovascular disease risk: tools for primary prevention. Am J Clin Nutr 2009; 89(5): 1509-1517.

8. National Cholesterol Education Program (NCEP) Expert Panel on Detection, Evaluation, and Treatment of High Blood Cholesterol in Adults (Adult Treatment Panel III). Third Report of the National Cholesterol Education Program (NCEP) Expert Panel on Detection, Evaluation, and Treatment of High Blood Cholesterol in Adults (Adult Treatment Panel III) final report. Circulation 2002;106 (25): 3143-3421.

9. European Atherosclerosis Society. Consensus position paper on plant sterols and plant stanols in the management of dyslipidaemia and prevention of cardiovascular disease. Atherosclerosis 2014; 232(2): 346-360

10. Köhler J, Teupser D, Elsässer A, Weingärtner O. Plant sterol enriched functional food and atherosclerosis. Br J Pharmacol 2017; 174(11):1281-1289.

11. QuillezJ, Garcia-Lorda P, Salas-Salvado J. Potential uses and benefits of phytosterols in diet: present situation and future directions. Clin Nutr 2003;22: 343-351.

12. Moreau RA, Nyström L, Whitaker BD, Winkler-Moser JK, Baer DJ, Gebauer SK et al. Phytosterols and their derivatives: Structural diversity, distribution, metabolism, analysis, and health-promoting uses. Prog Lipid Res 2018; 70: 35-61.

13. Erdem H, Tosun YK, Hazer O, Akkbik M. Determination of main plant sterols in turkish bread wheat (Triticum aestivum L.) by GC-MS. Turkish J Agric Food Sci Technol 2017; 5(7): 710-719.

14. Gylling H, Plat J, Turley S, Ginsberg HN, Ellegård L, Jessup W et al. Plant sterols and plant stanols in the management of dyslipidaemia and prevention of cardiovascular disease. Atherosclerosis 2014; 232(2): 346-360.

15. Yorulmaz A, Koç M, Bircan C. Farklı tsıtma tekniklerinin findık ve kanola yağının sterol bileșimine etkisi. Gtda 2017; 42 (2): 145-154.

16. Bozdoğan Konuşkan D. Hatay zeytinyağlarının yağ asidi ve sterol kompozisyonları. TURJAF 2017; 5(2): 170-175.

17. Ras RT, van der Schouw YT, Trautwein EA, Sioen I, Dalmeijer GW, Zock PL et al. Intake of phytosterols from natural sources and risk of cardiovascular disease in the European Prospective Investigation into Cancer and Nutrition-the Netherlands (EPIC-NL) population. Eur J Prev Cardiol 2015; 22(8): 1067-1075.

18. Sioen I, Matthys C, Huybrechts I, Van Camp J, De Henauw S. Consumption of plant sterols in Belgium: estimated intakes and sources of naturally occurring plant sterols and $\beta$-carotene. Br J Nutr 2011; 105(6): 960-966.

19. Klingberg S, Andersson H, Mulligan A, Bhaniani A, Welch A, Bingham S et al. Food sources of plant sterols in the EPIC Norfolk population. Eur J Clin Nutr 2008; 62(6): 695-703.

20. Escurriol V, Cofán M, Moreno-Iribas C, Larrañaga N, Martínez C, Navarro C et al. Phytosterol plasma concentrations and coronary heart disease in the prospective Spanish EPIC cohort. J Lipid Res 2010; 51: 618-624.

21. Wang P, Chen Y-m, He L-p, Chen C-g, Zhang B, Xue W-q, et al. Association of natural intake of dietary plant sterols with carotid intima-media thickness and blood lipids in chinese adults: a cross-section study. PLoS ONE 2012; 7(3): e32736.

22. Aksoy M. Ansiklopedik Beslenme, Diyet ve Gıda Sözlügüu. 1. Baskı. Ankara: Hatipoğlu Yayinevi; 2007. s:323.

23. Karampola M, Papandreou D, Makedou K. The role of Mediterranean diet in health and disease: an updated mini review. Nutrition \& Food Science 2011; 41(1): 63-72.

24. Jaceldo-Siegl K, Lütjohann D, Sirirat R, Mashchak A, Fraser GE, Haddad E. Variations in dietary intake and plasma concentrations of plant sterols across plant-based diets among North American adults. Mol Nutr Food Res 2017; 61(8). doi:10.1002/mnfr.201600828.

25. Gylling H, Miettinen. The effect of plant stanol and sterol-enriched foods on lipid metabolism, serum lipids and coronary heart disease. Ann Clin Biochem 2005 ;42: 254-263.

26. Champe PC, Harvey RA, Ferrier DR. Biyokimya. Ulukaya E, editör. Lippincott's Illustrated Reviews Serisinden. 3. Baskt. Nobel Tip Kitapevleri; 2007. s: 206.
27. De Smet E, Mensink RP, Plat J. Effects of plant sterols and stanols on intestinal cholesterol metabolism: Suggested mechanisms from past to present. Mol Nutr Food Res 2012; 56(7):1058-1072.

28. Ogbe RJ, Ochalefu DO, Mafulul SG, Olaniru OB. A review on dietary phytosterols: Their occurrence, metabolism and health benefits. Asian J Plant Sci Res 2015; 5(4):10-21.

29. de Jong A, Plat J, Mensink RP. Metabolic effects of plant sterols and stanols (Review). J Nutr Biochem 2003;14(7):362-369.

30. Ostlund RE, Mcgill JB, Zeng C, Covey DF, Stearns J, Stenson WF et al. Gastrointestinal absorption and plasma kinetics of soy 45 -phytosterols and phytostanols in humans. Am J Physiol Endocrinol Metab 2002; 282: E911-E916.

31. Gylling H, Simonen P. Phytosterols, phytostanols, and lipoprotein metabolism. Nutrients 2015; 7(9): 7965-7977.

32. Demonty I, Ras RT, van der Knaap HC, Duchateau GS, Meijer L, Zock PL et al. Continuous dose-response relationship of the LDL-cholesterol-lowering effect of phytosterol intake. J Nutr 2009;139(2): 271-284.

33. Li YC, Li CL, Li R, Chen Y, Zhang M, Guo PP et al. Associations of dietary phytosterols with blood lipid profiles and prevalence of obesity in Chinese adults, a cross-sectional study. Lipids Health Dis 2018;17(1): 54.

34. Juritsch A, Tsai YT, Patel MS, Rideout TC. Transcriptional control of enterohepatic lipid regulatory targets in response to early cholesterol and phytosterol exposure in apoE-/- mice. BMC Res Notes 2017; 10: 529.

35. Harding SV, Rideout TC, Jones PJH. Hepatic nuclear sterol regulatory binding element protein 2 abundance is decreased and that of ABCG5 increased in male hamsters fed plant sterols. J Nutr 2010; 140(7):1249-1254.

36. Rideout TC, Carrier B, Wen S, Raslawsky A, Browne RW, Harding SV. Complementary cholesterol-lowering response of a phytosterol/ $\alpha$-lipoic acid combination in obese zucker rats. J Diet Suppl 2016; 13(3): 283-299.

37. Brauner R, Johannes C, Ploessl F, Bracher F, Lorenz RL. Phytosterols reduce cholesterol absorption by inhibition of 27-Hydroxycholesterol generation, Liver X Receptor a activation, and expression of the basolateral sterol exporter ATP-Binding Cassette A1 in Caco-2 enterocytes. J Nutr 2012; 142(6): 981-989.

38. Talati R, Sobieraj DM, Makanji SS, Phung OJ, Coleman CI. The comparative efficacy of plant sterols and stanols on serum lipids: a systematic review and meta-analysis. J Am Diet Assoc 2010; 110(5): 719-726.

39. Racette SB, Lin X, Lefevre M, Spearie CA, Most MM, Ma L et al. Dose effects of dietary phytosterols on cholesterol metabolism: a controlled feeding study. Am J Clin Nutr 2010; 91(1): 32-38.

40. Sialvera TE, Pounis GD, Koutelidakis AE, Richter DJ, Yfanti G, Kapsokefalou M et al. Phytosterols supplementation decreases plasma small and dense LDL levels in metabolic syndrome patients on a westernized type diet. Nutr Metab Cardiovasc Dis 2012; 22(10): 843-848.

41. Cheung CL, Ho DKC, Sing CW, Tsoi MF, Cheng VKF, Lee GKY et al. Randomized controlled trial of the effect of phytosterols-enriched low fat milk on lipid profile in Chinese. Nature 2017; 7: 41084.

42. Chien YL, Wu LY, Lee TC, Hwang LS. Cholesterol-lowering effect of phytosterol-containing lactic-fermented milk powder in hamsters. Food Chem 2010; 119(3): 1121-1126.

43. European Food Safety Authority Panel on Dietetic Products, Nutrition and Allergies (NDA). Scientific Opinion on the substantiation of a health claim related to $3 \mathrm{~g} /$ day plant sterols/ stanols and lowering blood LDL-cholesterol and reduced risk of (coronary) heart disease pursuant to Article 19 of Regulation (EC) No 1924/2006. EFSA Journal 2012; 10(5): 2693.

44. Rideout TC, Harding SV, Jones PJH. Consumption of plant sterols reduces plasma and hepatic triglycerides and modulates the expression of lipid regulatory genes and de novo lipogenesis in C57BL/6J mice. Mol Nutr Food Res 2010; 54(1): 7-13.

45. Párraga-Martínez I, López-Torres-Hidalgo JD, del Campo-del Campo JM, Galdón-Blesa MP, Precioso-Yáñez JC, Rabanales-Sotos J et al. Long-term effects of plant stanols on the lipid profile of patients with hypercholesterolemia. A randomized clinical trial. Rev Esp Cardiol 2015; 68(8): 665-671.

46. Amir Shaghaghi M, Abumweis SS, Jones PJ. Cholesterol-lowering efficacy of plant sterols/ stanols provided in capsule and tablet formats: results of a systematic review and meta-a nalysis. J Acad Nutr Diet 2013; 113(11): 1494-1503.

47. Ras RT, Geleijnse JM, Trautwein EA. LDL-cholesterol-lowering effect of plant sterols and stanols across different dose ranges: a meta-analysis of randomised controlled studies. $\mathrm{BrJ}$ Nutr 2014; 112(2): 214-219.

48. Xu Z, Le K, Moghadasian MH. Long-term phytosterol treatment alters gene expression in the liver of apo E-deficient mice. J Nutr Biochem 2008; 19(8):545-554. 
Sakarya Tip Dergisi 2019;9(2):218-229

ÇEKİĊ ve Ark., Bitkisel Steroller/Stanoller ve Kardiyovasküler Sağlık

49. Bombo RPA, Afonso MS, Machado RM, Ferrari Lavrador MS, Nunes VS, Quintão ER et al. Dietary phytosterol does not accumulate in the arterial wall and prevents atherosclerosis of LDLr-KO mice. Atherosclerosis 2013; 231(2): 442-447.

50. Moghadasian MH, Alsaif M, Le K, Gangadaran S, Masisi K, Beta T et al. Combination effects of wild rice and phytosterols on prevention of atherosclerosis in LDL receptor knockout mice. J Nutr Biochem 2016; 33: 128-135.

51. Das R, Dimitrova N, Xuan Z, Rollins RA, Haghighi F, Edwards JR et al. Computational prediction of methylation status in human genomic sequences. Proc Natl Acad Sci USA 2006; 103(28):10713-10716.

52. Lim U, Song MA. Dietary and lifestyle factors of DNA methylation. Methods Mol Biol 2012; 863: 359-376.

53. Sabeva NS, McPhaul CM, Li X, Cory TJ, Feola DJ, Graf GA. Phytosterols differentially influence abc transporter expression, cholesterol efflux and inflammatory cytokine secretion in macrophage foam cells. J Nutr Biochem 2011; 22(8): 777-783.

54. Nestel P, Cehun M, Pomeroy S, Abbey M, Weldon G. Cholesterol-lowering effects of plant sterol esters and non-esterified stanols in margarine, butter and low-fat foods. Eur J Clin Nutr 2001; 55(12):1084-1090.

55. De Graaf J, De Sauvage-Nolting PR, Van Dam M, Belsey EM, Kastelein JJ, Haydn Pritchard $P$ et al. Consumption of tall oil-derived phytosterols in a chocolate matrix significantly decrease plasma total and low-density lipoprotein cholesterol levels. Br J Nutr 2002; 88(5): 479-488.

56. Noakes M, Clifton P, Ntanios F, Shrapnel W, Record I, McInerney J. An increase in dietary carotenoids when consuming plant sterols or stanols is effective in maintaining plasma carotenoid concentrations. Am J Clin Nutr 2002; 75(1): 79-86.

57. O'Neill FH, Brynes A, Mandeno R, Rendell N, Taylor G, Seed M et al. Comparison of the effects of dietary plant sterol and stanol esters on lipid metabolism. Nutr Metab Cardiovasc Dis 2004; 14:133-142.

58. Hansel B, Nicolle C, Lalanne F, Tondu F, Lassel T, Donazzolo Y et al. Effect of low-fat, fermented milk enriched with plant sterols on serum lipid profile and oxidative stress in moderate hypercholesterolemia. Am J Clin Nutr 2007; 86(3):790-796.

59. Li NY, Li K, Qi Z, Demonty I, Gordon M, Francis L et al. Plant sterol-enriched milk tea decreases blood cholesterol concentrations in Chinese adults: a randomised controlled trial. Br J Nutr 2007; 98(5): 978-983.

60. De Jong A, Plat J, Bast A, Godschalk RW, Basu S, Mensink RP. Effects of plant sterol and stanol ester consumption on lipid metabolism, antioxidant status and markers of oxidative stress, endothelial function and low-grade inflammation in patients on current statin treatment. Eur J Clin Nutr 2008; 62(2): 263-273.

61. Mannarino E, Pirro M, Cortese C, Lupattelli G, Siepi D, Mezzetti A et al. Effects of a phytosterol-enriched dairy product on lipids, sterols and 8-isoprostane in hypercholesterolemic patients: A multicenter Italian study. Nutr Metab Cardiovasc Dis 2009; 19(2): 84-90.

62. Bañuls C, Martínez-Triguero ML, López-Ruiz A, Morillas C, Jarabo MM, Bellod L et al. Serum lipid responses to phytosterol-enriched milk in a moderate hypercholesterolemic population is not affected by apolipoprotein E polymorphism or diameter of low-density lipoprotein particles. Eur J Clin Nutr 2011; 65(2): 255-261.

63. Vásquez-Trespalacios EM, Romero-Palacio J. Efficacy of yogurt drink with added plant stanol esters (Benecol ${ }^{\circ}$, Colanta) in reducing total and LDL cholesterol in subjects with moderate hypercholesterolemia: a randomized placebo-controlled crossover trial NCT01461798. Lipids Health Dis 2014;13: 125 .

64. Jacobs DM, Mihaleva VV, van Schalkwijk DB, de Graaf AA, Vervoort J, van Dorsten FA et al. The effect of plant sterols and different low doses of omega-3 fatty acids from fish oil on lipoprotein subclasses. Mol Nutr Food Res 2015; 59(9):1745-57.

65. Kietsiriroje N, Kwankaew J, Kitpakornsanti S, Leelawattana R. Effect of phytosterols and inulin-enriched soymilk on LDL-cholesterol in Thai subjects: a double-blinded randomized controlled trial. Lipids Health Dis 2015;14: 146.

66. Padro T, Vilahur G, Sánchez-Hernández J, Hernández M, Antonijoan RM, Perez A. Lipidomic changes of LDL in overweight and moderately hypercholesterolemic subjects taking phytosterol-and omega-3-supplemented milk. J Lipid Res 2015; 56(5):1043-56.

67. Ras RT, Fuchs D, Koppenol WP, Garczarek U, Greyling A, Keicher C et al. The effect of a low-fat spread with added plant sterols on vascular function markers: results of the Investigating Vascular Function Effects of Plant Sterols (INVEST) study. Am J Clin Nutr 2015;101(4):733-41

68. Dong S, Zhang R, Ji YC, Hao JY, Ma WW, Chen XD, Xiao R, Yu HL. Soy milk powder supplemented with phytosterol esters reduced serum cholesterol level in hypercholesterolemia independently of lipoprotein E genotype: a random clinical placebo-controlled trial. Nutr Res 2016; 36(8):879-84.

69. Ras RT, Koppenol WP, Garczarek U, Otten-Hofman A, Fuchs D, Wagner F et al. Increases in plasma plant sterols stabilize within four weeks of plant sterol intake and are independent of cholesterol metabolism. Nutr Metab Cardiovasc Dis 2016; 26(4):302-309.

70. Zhu J, Shi Y, Wang Y, Wang L, Zhao Z. Effect of milk enriched with phytosterol ester on blood cholesterol of patients with hypercholesterolemia: a randomized controlled trial. Wei Sheng Yan Jiu 2016; 45(5):718-732

71. Cicero AFG, Fogacci F, Rosticci M, Parini A, Giovannini M, Veronesi $M$ et al. Effect of a short-term dietary supplementation with phytosterols, red yeast rice or both on lipid pattern in moderately hypercholesterolemic subjects: a three-arm, double-blind, randomized clinical trial. Nutr Metab (Lond) 2017;14: 61

72. Ferguson JJA, Stojanovski E, MacDonald-Wicks L, Garg ML. Curcumin potentiates cholesterol-lowering effects of phytosterols in hypercholesterolaemic individuals. A randomised controlled trial. Metabolism 2018; 82: 22-35.

73. Moghadasian MH, McManus BM, Pritchard PH, Frohlich JJ. Tall oil-derived phytosterols reduce atherosclerosis in apoe-deficient mice. Arterioscler Thromb Vasc Biol 1997; 17(1):119-126.

74. Yeganeh B, Moshtaghi-Kashanian GR, DeClercq V, Moghadasian MH. Combination of dietary phytosterols plus niacin or fenofibrate: effects on lipid profile and atherosclerosis in apo E-KO mice. J Nutr Biochem 2005; 16(4): 222-228.

75. Brufau G, Kuipers F, Lin Y, Trautwein EA, Groen AK. A reappraisal of the mechanism by which plant sterols promote neutral sterol loss in mice. PLoS ONE 2011; 6(6): e21576.

76. Awaisheh SS, Khalifeh MS, Al-Ruwaili MA, Khalil OM, Al-Ameri OH, Al-Groom R. Effect of supplementation of probiotics and phytosterols alone or in combination on serum and hepatic lipid profiles and thyroid hormones of hypercholesterolemic rats. J Dairy Sci 2013; 96(1): 9-15.

77. Schonewille M, Brufau G, Shiri-Sverdlov R, Groen AK, Plat J. Serum TG-lowering properties of plant sterols and stanols are associated with decreased hepatic VLDL secretion. J Lipid Res 2014; 55: 2554-2561.

78. Botelho PB, Guimarães JP, Mariano KR, Afonso MS, Koike MK, Lottenberg AMP et al. Effect of echium oil combined with phytosterols on biomarkers of atherosclerosis in LDLrknockout mice: echium oil is a potential alternative to marine oils for use in functional foods. Eur J Lipid Sci Technol 2015;117(10): 1561-1568.

79. Deng Q, Yu X, Xu J, Kou X, Zhang $M$, Huang $F$ et al. Single frequency intake of $\alpha$-linolenic acid rich phytosterol esters attenuates atherosclerosis risk factors in hamsters fed a high fat diet. Lipids Health Dis 2016;15: 23.

80. Cedó L, Santos D, Ludwig IA, Silvennoinen R, García-León A, Kaipiainen L et al. Phytosterol-mediated inhibition of intestinal cholesterol absorption in mice is independent of liver $X$ receptor. Mol Nutr Food Res 2017; 61(9): 1700055.

81. Nashed B, Yeganeh B, HayGlass KT. Antiatherogenic effects of dietary plant sterols are associated with inhibition of proinflammatory cytokine production in Apo E-KO mice. J Nutr 2005; 135(10): 2438-2444.

82. Moghadasian MH, Nguyen LB, Shefer S, McManus BM, Frohlich JJ. Histologic, hematologic, and biochemical characteristics of apo E-deficient mice: effects of dietary cholesterol and phytosterols. Lab Investig 1999; 79(3): 355-364.

83. Piepoli MF, Hoes AW, Agewall S, Albus C, Brotons C, Catapano AL et al. 2016 European Guidelines on cardiovascular disease prevention in clinical practice: The Sixth Joint Task Force of the European Society of Cardiology and Other Societies on Cardiovascular Disease Prevention in Clinical Practice (constituted by representatives of 10 societies and by invited experts) Developed with the special contribution of the European Association for Cardiovascular Prevention \& Rehabilitation (EACPR). Eur Heart J 2016; 37: 2315-2381.

84. Cantrill R, Kawamura Y. Phytosterols, phytostanols and their esters. Chemical and technical assessment (CTA) for the 69th Joint FAO/ WHO Expert Committee on Food Additives (JECFA), 2008.

85. American Heart Associations. What's new in the 2007 ACC/AHA Chronic Stable Angina Focused Update. Erișim adresi: https://professional.heart.org/professional/ScienceNews/ UCM_465990_Whats-new-in-the-2007-ACCAHA-Chronic-Stable-Angina-Focused-Update.jsp. Erişim tarihi: 10.11.2018

86. Stone NJ, Robinson JG, Lichtenstein AH, Bairey Merz CN, Bum CB et al. 2013 ACC/AHA guideline on the treatment of blood cholesterol to reduce atherosclerotic cardiovascular risk in adults: a report of the American College of Cardiology/American Heart Association Task Force on Practice Guidelines. Circulation 2014; 129(25 Suppl 2):S1-S45. doi: 10.1161/01. cir.0000437738.63853.7a.

87. Cooper A, Nherera L, Calvert N, O'Flynn N, Turnbull N, Robson J et al. Clinical guidelines and evidence review for lipid modification: cardiovascular risk assessment and the primary and secondary prevention of cardiovascular disease. London: National Collaborating Centre for Primary Care and Royal College of General Practitioners; 2008. p.106.

88. U.S. Food and Drug Administration. FDA Letter Regarding Enforcement Discretion With 
Sakarya Tip Dergisi 2019;9(2):218-229

ÇEKİCİ ve Ark., Bitkisel Steroller/Stanoller ve Kardiyovasküler Sağlık

Respect to Expanded Use of an Interim Health Claim Rule About Plant Sterol/Stanol Esters and Reduced Risk of Coronary Heart Disease. (2003). Erişim adresi: https://www.fda.gov/ Food/LabelingNutrition/ucm074779.htm. Erişim tarihi: 12.11.2018.

89. U.S. Food and Drug Administration. Food Labeling; Health Claims: Phytosterols and Risk of Coronary Heart Disease (2010). Erişim adresi: https://www.regulations.gov/document?D=FDA-2000-P-0102-0006. Erisim tarihi: 12.01.2019.

90. Jialal I. The role of dietary supplemantation with plant sterols and stanols in the prevention of cardiovascular disease. Nutr Rev 2006; 64: 348-354.

91. Regulation (EC) No. 258/97 of the European Parliament and of the Council of 27 January 1997 concerning novel foods and novel food ingredients. Official Journal of the European Union (OJ) L 43, 14.21997, p. 1-6. Las amended by Regulation (EC) 1829/2003, OJ L 268, 18.10.2003, p. 1-23.

92. ResmiGazete. Erișimadresi:http://www.resmigazete.gov.tr/eskiler/2017/01/20170126M1-5. htm. Erişim tarihi: 20.05.2019.

93. Mensink RP, de Jong A, Lutjohann D, Haenen GR, Plat J. Plant stanols dose-dependently decrease LDL-cholesterol concentrations, but not cholesterol-standardized fat-soluble antioxidant concentrations, at intakes up to $9 \mathrm{~g} / \mathrm{d}$. Am J Clin Nutr 2010; 92(1): 24-33.

94. Jong A, Plat J, Mensink RP. Metabolic effects of plant sterols and stanols.J Nutr Biochem 2003; 14: 362-369.

95. Law M. Plant sterol and stanol margarines and health. Br Med J 2000; 320: 861-864.

96. European Food Safety Authority. Consumption of food and beverages with added plant sterols in the European Union. Scientific report. EFSA Journal 2008; 133:1-21.

97. Law MR, Wald NJ, Rudnicka AR. Quantifying effect of statins on low density lipoprotein cholesterol, ischaemic heart disease, and stroke: Systematic review and meta-analysis. BMJ 2003;326 (7404):1423.

98. Lichtenstein AH, Deckelbaum RJ: AHA Science Advisory. Stanol/sterol estercontaining foods and blood cholesterol levels. A statement for healthcare professionals from the Nutrition Committee of the Council on Nutrition, Physical Activity, and Metabolism of the American Heart Association. Circulation 2001; 103:1177-1179. 